\title{
Prenatal diagnosis of criss-cross heart with congenitally corrected transposition of the great arteries and aortic coarctation - case report
}

Julia Murlewska ${ }^{1}$, Joanna Kućmierz ${ }^{2}$, Sławomir Witkowski ${ }^{3}$, Agnieszka Żalińska ${ }^{1}$, and Maria Respondek-Liberska ${ }^{2}$

${ }^{1}$ Polish Mother's Memorial Hospital-Research Institute

${ }^{2}$ Medical University of Lodz

${ }^{3}$ Nicolaus Copernicus University in Torun Ludwik Rydygier Collegium Medicum in Bydgoszcz Medical Library

November 9, 2020

\begin{abstract}
This paper presents an extremely rare and difficult case report of criss-cross heart (CCH) with a combination of cc-TGA and aortic coarctation of the fetal heart at 33 weeks of gestation. Despite very complicated heart anatomy, the proper perinatal care and early cardiac surgery allowed us to observe normal development of the child without any problems during his first six and ten months of postnatal life. The impossibility to: image proper four-chamber view, obtain parallel tricuspid and mitral valve, visualize symmetrical valve motion and laminar flow from the atrium to the ventricle might be the first clues to diagnose $\mathrm{CCH}$.
\end{abstract}

Title page:

Prenatal diagnosis of criss-cross heart with congenitally corrected transposition of the great arteries and aortic coarctation - case reportJulia Murlewska 1, Joanna Kućmierz 2, Sławomir Witkowski 3,Agnieszka Żalińska 4, Maria Respondek-Liberska5

Department of Prenatal Cardiology Polish Mother's Memorial Hospital, Ambassador of the International Society of Ultrasound in Obstetrics and Gynecology

Board of the Polish Prenatal Cardiology Society

1. Medical University of Lodz, Student of Medical Faculty. Individual training at the Department of Prenatal Cardiology

2. Ludwik Rydygier Collegium Medicum in Bydgoszcz, Student of Medical Faculty. Individual training at the Department of Prenatal Cardiology

3. Department of Prenatal Cardiology Polish Mother's Memorial Hospital

Department of Obstetrics, Perinatology and Gynecology, Polish Mother's Memorial Hospital Research Institute

President of the Polish Prenatal Cardiology Society

Prenatal Cardiology Journal Co-editor Head of Department of Prenatal Cardiology Polish Mother's Memorial Hospital, Research Institute Head of Department for Fetal Malformations Diagnosis and Prevention Depart- 
ment of Prenatal Cardiology of Polish Mother's Memorial Hospital Medical University of Lodz, Department for Congenital Malformations and Prevention, Faculty of Public Health

Corresponding author: Julia Murlewska, Ul Rzgowska 281/289 Łódź Poland Department of Prenatal Cardiology, Polish Mother's Memorial Hospital Research Institute, Tel.com: +48 503132 141, Email: juliamurlewska.jm@gmail.com

\section{Authors' contributions:}

J. Murlewska: collecting data, first draft, work with manuscript, manuscript writing

Joanna Kućmierz: collecting data, work with manuscript

Sławomir Witkowski: proofreading

Agnieszka Żalińska: final version, correction

M. Respondek-Liberska: project development, correction, final version

Statement: All authors read and approved the final version of the manuscript.

Acknowledgement: Cardiac surgery was performed by Prof. Jacek Moll and his team of Pediatric Cardiac Surgery Department of the Polish Mother's Memorial Hospital Research Institute. Angio CT was kindly provided by the Department of Radiology of the Polish Mother's Memorial Hospital Research Institute. We also would like to thank our colleges from Obstetrics Departments, Neonatology Department, Pediatric Cardiology Department and Intensive Care Department for cooperation and appreciation our input in spreading up their daily work.

Funding: The article was not financed from external sources.

Statement of Ethics: Ethical approval, institutional review board (IRB), was not required due to the fact that the presented case is a retrospective clinical analysis. The informed consent was obtained from the patients.

Disclosure Statement: The authors have no conflicts of interest to declare.

Keywords: criss-cross heart, congenitally corrected transposition of the great arteries, coarctation of the aorta, hypoplastic right ventricle

Abstract:

This paper presents an extremely rare and difficult case report of criss-cross heart $(\mathrm{CCH})$ with a combination of cc-TGA and aortic coarctation of the fetal heart at 33 weeks of gestation. Despite very complicated heart anatomy, the proper perinatal care and early cardiac surgery allowed us to observe normal development of the child without any problems during his first six and ten months of postnatal life. The impossibility to: image proper four-chamber view, obtain parallel tricuspid and mitral valve, visualize symmetrical valve motion and laminar flow from the atrium to the ventricle might be the first clues to diagnose $\mathrm{CCH}$.

\section{Case report}

We present a very rare and complex heart malformation involving compilation of criss-cross heart and congenitally corrected transposition of the great arteries-ccTGA at 33 weeks of gestation. The examined fetus had morphological left ventricle on the right side of his body and hypoplastic morphological right ventricle on the left side of his body. To describe the anatomy of this malformation, it was important to provide a methodical analysis of the archived off-line files in slow motion (Clip1, Clip 2). Fetal heart malformation was observed for the first time at $30^{\text {th }}$ week of gestation and was described as ventricular septum defect. At 33th week of the gestation large VSD with an incorrect view of superior mediastinum was detected. It was impossible to obtain a regular 4-chamber view of the heart. In our case the attachments of the left and right atrioventricular valves were positioned perpendicularly to each other. Left atrium was attached by the twisted atrioventricular valve to the hypoplastic ventricle of the right ventricle, whereas the 
right atrium was attached to the left ventricle. There were also discordant atrioventricular connections: on the left side there was small right ventricle and on the right side there was large left ventricle (Clip 1). The position of the right ventricle/ left ventricle was in an up/down relation to each other. Ventricular septal defect was present in the middle "inflow" part of the septum. The aorta emerged from the morphological hypoplastic right ventricle and under the aorta there was pulmonary trunk widening distally into the arterial duct. The fetus had other four echo-sonographical exams (Table 1), which showed small deceleration in fetal growth since $33^{\text {rd }}$ week of gestation but with good umbilical Doppler blood flows (UMB PI), normal heart rate up to $38^{\text {th }}$ week of gestation (according to last menstrual period) and $36^{\text {th }}$ week of gestation (according to biometry). The heart size was at the upper limit of the norm, whereas pulmonary trunk increased in size up to $13 \mathrm{~mm}$ three weeks before delivery ( $Z$ score for the last measurements was $+2,47$ ). The growth of the aorta stopped at the same time and achieved a maximum value of $7 \mathrm{~mm}(Z$ score for the last measurements was $-0,43)$. The AO/MPA ratio was 0,54 [1]. There was appropriate blood flow through the foramen ovale from the right to the left side of the heart and the size of VSD did not increase. Due to the parallel location of large vessels of superior mediastinum, prenatal presentation of the optimal sagittal cross-section of the aortic arch was difficult, however the accelerated gradient of flow through the aortic isthmus was not observed. There was spontaneous delivery at term at $40^{\text {th }}$ week of the gestation and baby boy was born with the birth weight of $3000 \mathrm{~g}$ and was assigned ten points according to the Apgar Score. The Prostin infusion started just after birth to maintain the arterial duct patency. Postnatal echocardiography, chest X-rays and angio-computed tomography (Fig. 1-2) confirmed the prenatal findings and, in addition, allowed us to detect aortic coarctation (Fig.2). The type A of the aortic arch coarctation was postnatally demonstrated during echocardiography at the level below the left subclavian artery (LSA), proximally to the arterial duct. The aortic arch reconstruction surgery with pulmonary trunk banding was performed on $8^{\text {th }}$ day of postnatal life. The child was asymptomatic at the age of six and ten.

$\mathrm{CCH}$ is a cardiac malformation which is very difficult to diagnose both prenatally and postnatally (Tab 2) [2-5]. Development of the heart block, tricuspid regurgitation, right ventricular dysfunction as a systemic chamber and congestive heart failure is possible at every stage of the life of a child. The prognosis depends on the type of associated abnormalities. The tricuspid regurgitation is considered as the risk factor and sign of developing cardiac failure, which may lead to death or necessitate cardiac transplantation [6-11]. Fetal echocardiography monitoring allowed to prepare the pregnant woman and medical staff for save delivery in tertiary center for obstetrics \& cardiology. Despite very complicated heart anatomy, the proper perinatal care and early cardiac surgery allowed us to observe normal development of the child without any problems during his first six and ten months of postnatal life. The impossibility to: image proper four-chamber view, obtain parallel tricuspid and mitral valve, visualize symmetrical valve motion and laminar flow from the atrium to the ventricle might be the first clues to diagnose $\mathrm{CCH}$.

\section{References:}

1. Schneider C, McCrindle BW, Carvalho JS, Hornberger, LK, McCarthy P, Daubeney PEF. Development of $Z$-scores for fetal cardiac dimensions from echocardiography. Ultrasound Obstet Gynecol. 2005; 26: $599-605$

2. Ngeh NN, Api O, Iasci A., Ho SY, Carvalho JS. Criss-cross heart: report of three cases with double inlet ventricles diagnosed in utero. Ultrasound Obstet Gynecol. 2008; 31 (4): 461-465.

3. Ayabakan, C., Binnetoğlu, K., Sarısoy, Ö. and Tokel, K. Crisscross Heart Diagnosed In Utero. Congenit Heart Dis. 2013; 8: E153-E156. doi: 10.1111/j.1747-0803.2012.00716.x

4. Kim SK, Tanaka M, Umezu M, Oda H, Asai S, Higuchi T, Kadohira I, Minegishi K, Miyakoshi K, Yoshimura Y. Congenitally corrected transposition of the great arteries. J Med Ultrason. 2012; 39 (1): pp25-27.

5. McEwing RL, Chaoui R. Congenitally corrected transposition of the great arteries: clues for prenatal diagnosis. Ultrasound Obstet Gynecol. 2004; 23: 68-72.

6. Symons JC, Shinebourne EA, Joseph MC, Lincoln C, Ho Y, Anderson RH. Criss-cross heart with congenitally corrected transposition: report of a case with d-transposed aorta and ventricular preexcitation. Eur J Cardiol. 1977;5(6):493-505. 
7. Hu J, Ren W. Criss cross heart with situs inversus in pregnancy. A rare case report and literature review. Echocardiography. 2018. https://doi.org/10.1111/echo.14155.

8. Ren S, Ma C, Li S. Criss-cross heart with double-outlet right ventricle, subpulmonary ventricular septal defect, and bicuspid pulmonary valve. J Clin Ultrasound. 2019;47(5):315-318.

9. Ravi P, Fruitman D, Mills L, Colen T, Hornberger LK. Prenatal Diagnosis of the Criss-Cross Heart. Am J Cardiol. 2017;119(6):916-922.

10. Wilkinson JL, Anderson RH. Anatomy of Discordant Atrioventricular Connections. World Journal for Pediatric and Congenital Heart Surgery, 2011; 2(1), 43-53.

11. Zeigler S, Mainwaaring RD, Ounn R, Petrossian E,. Hanley FL. Double-switch repair of corrected transposition in association with criss-cross atrial morphology. The annals of Thoracic Surgery. 2016; 101: $1208-1210$.

Figures, clips, tables legend:

Clip 1:

Criss-cross heart with congenitally corrected transposition of the great arteries: four-chamber view: the left atrioventricular valve is inserted in perpendicular view to the right atrioventricular valve. Left atrium is attached by the twisted atrioventricular valve to the hypoplastic ventricle of the right ventricle.. The right atrium is attached to the morphologic left ventricle. There are discordant atrioventricular connections: on the left side there is small right ventricular and on the right side there is large left ventricle. The position of the right ventricle/ left ventricle is in an up/down relation to each other. Ventricular septal defect is presented in the middle "inflow" part of the septum The aorta emerges from the morphological hypoplastic right ventricle and under the aorta there was pulmonary trunk widening distally into the arterial duct. Clip 2: Criss-cross heart with congenitally corrected transposition of the great arteries: color Doppler blood flow from the left atrium through the tricuspid valve was directed to the right ventricle, from the right atrium through the mitral valve directly to the left ventricle, and from the right atrium indirectly through the large VSD to the right ventricle and the blood was mixed between the ventricles. Table 1: Prenatal echocardiographic parameters: fECHO-fetal echocardiography Fig. 1: Newborn Chest X-ray on the 1st day of postnatal life Fig. 2: Newborn angio CT on the $5^{\text {th }}$ day of postnatal life: the aorta in front leaving the hypoplastic right ventricle. The aorta is two times narrower than pulmonary trunk attached through arterial duct to the descending aorta. Table 2: Reports of prenatal diagnoses of criss cross heart in the medical literature (PUB MED) and our case

Tab.1:

\begin{tabular}{llllll}
\hline & $\mathbf{1}^{\text {st }} \mathbf{f E C H O}$ & $\mathbf{2}^{\text {nd }} \mathbf{f E C H O}$ & $\mathbf{3}^{\text {rd }} \mathbf{f E C H O}$ & $\mathbf{4}^{\text {th }} \mathbf{f E C H O}$ & $\mathbf{5}^{\text {th }} \mathbf{f E C H O}$ \\
\hline GA by LMP & 31,5 & 33,4 & 37,0 & 38,0 & 39,4 \\
GA by US & 31,2 & 34,0 & 35,5 & 36,0 & 36,3 \\
UMB PI & 1,06 & 1,1 & 0,96 & 0,73 & 0,9 \\
Fetal & Cephalic & Cephalic & Cephalic & Cephalic & Cephalic \\
presentation & & & & & \\
AFI [cm] & & 13 & $6,5 \mid$ & $7,2 \mid$ & $4 \mid$ \\
EFW (g) & 1798,1 & $2231+/-326$ & $2754+/-402$ & $2760+/-403$ & $2919+/-426$ \\
FHR (bpm) & 150 & 140 & 140 & 138 & 104 \\
Axis of heart & - & - & $75^{\circ}$ & $75^{\circ}$ & - \\
AP & - & - & 44 & 45 & 46 \\
HA $/ \mathbf{C A}$ & 0,36 & - & $0,45 \mid$ & $0,4 \mid$ & 0,3 \\
PA [mm] & 8,1 & 10 & 13 & 13 & 7 \\
AO [mm] & 5 & 4,7 & 7 & 7 & - \\
TV [mm] & 7,5 & 7 & - & - & - \\
MV [mm] & 8,4 & 11 & - & R-L & R-L \\
FO [mm] & - & 4,3 & & & \\
\hline
\end{tabular}


Tab.2:

\begin{tabular}{|c|c|c|c|c|}
\hline Authors: & $\begin{array}{l}\text { Year of } \\
\text { publication: }\end{array}$ & $\begin{array}{l}\text { Prenatal } \\
\text { diagnosis at [wks]: }\end{array}$ & $\begin{array}{l}\text { Additional } \\
\text { cardiac and/or } \\
\text { extracardiac } \\
\text { anomalies: }\end{array}$ & Follow-up: \\
\hline Ngeh N, et al.[2] & 2008 & 19 wks & $\begin{array}{l}\text { DORV-double } \\
\text { outlet right ventricle } \\
\text { with a right-sided } \\
\text { rudminentary left } \\
\text { ventricle }(\mathrm{LV})\end{array}$ & $\begin{array}{l}\text { Termination of } \\
\text { pregnancy, } \\
\text { postmortem } \\
\text { examination } \\
\text { confirmed the US } \\
\text { findings }\end{array}$ \\
\hline Ngeh N, et al.[2] & 2008 & 20 wks & $\begin{array}{l}\text { DORV with } \\
\text { significant } \\
\text { pulmonary stenosis } \\
\text {, with increased } \\
\text { velocity across the } \\
\text { pulmonary outflow } \\
\text { tract and reversal } \\
\text { flow in the arterial } \\
\text { duct. }\end{array}$ & $\begin{array}{l}\text { Male infant } \\
\text { delivered at term } \\
\text { and prostaglandin E } \\
\text { was introduced, } \\
4 \text { days a modified } \\
\text { Blalock-Taussig } \\
\text { shunt } \\
\text { with plans for } \\
\text { subsequent } \\
\text { univentricular } \\
\text { repair. (Fontan } \\
\text { type). }\end{array}$ \\
\hline Ngeh N, et al. [2] & 2008 & $23 \mathrm{wks}$ & $\begin{array}{l}\text { DIRF with } \\
\text { pulmonary atresia }\end{array}$ & $\begin{array}{l}\text { Termination of } \\
\text { pregnancy, } \\
\text { post-mortem } \\
\text { confirmation of the } \\
\text { prenatal diagnosis. }\end{array}$ \\
\hline $\begin{array}{l}\text { Ayabakan C, et al } \\
{[3]}\end{array}$ & 2013 & & $\begin{array}{l}\text { Tricuspid atresia } \\
\text { DORV } \\
\text { Pulmonary stenosis }\end{array}$ & \\
\hline Kim SK, et al [4] & 2012 & 29 wks & $\begin{array}{l}\text { No additional } \\
\text { cardiac anomalies }\end{array}$ & $\begin{array}{l}\text { Patent ductus } \\
\text { arteriosus with } \\
\text { bidirectional flow }\end{array}$ \\
\hline
\end{tabular}




\begin{tabular}{|c|c|c|c|c|}
\hline Authors: & $\begin{array}{l}\text { Year of } \\
\text { publication: }\end{array}$ & $\begin{array}{l}\text { Prenatal } \\
\text { diagnosis at [wks]: }\end{array}$ & $\begin{array}{l}\text { Additional } \\
\text { cardiac and/or } \\
\text { extracardiac } \\
\text { anomalies: }\end{array}$ & Follow-up: \\
\hline $\begin{array}{l}\text { McEwing RL, } \\
\text { Chaoui R. [5] }\end{array}$ & 2004 & $27 \mathrm{wks}$ & $\begin{array}{l}\text { Muscular VSD } \\
\text { IUGR } \\
\text { Atrioventricular } \\
\text { block }\end{array}$ & $\begin{array}{l}\text { A male newborn, } \\
\text { born at } 38 \text { th week } \\
\text { birth weight } 2890 \mathrm{~g} \\
\text { Discharged at } 6 \\
\text { days of postnatal } \\
\text { life, age } 12 \text { months } \\
\text { echocardiography } \\
\text { demonstrated } \\
\text { spontaneus closure } \\
\text { of the VSD, } \\
4 \text { years of age } \\
\text { intermittent } \\
\text { bradycardia, } \\
\text { ECG:an } \\
\text { intermittent } \\
\text { atrioventricular } \\
\text { block with a } \\
\text { ventricular rate } \\
55 \text { bpm, } \\
5 \text { years of age } \\
\text { pacemaker insertion } \\
6 \text { years of age, Alive } \\
\& \text { Well with good } \\
\text { cardiac function. }\end{array}$ \\
\hline $\begin{array}{l}\text { McEwing RL, } \\
\text { Chaoui R. [5] }\end{array}$ & 2003 & $20 \mathrm{wks}$ & $\begin{array}{l}\text { Subpulmonic VSD } \\
\text { Higher peak } \\
\text { velocity across the } \\
\text { PAV-105cm/s, } \\
\text { suggesting possible } \\
\text { pulmonary stenosis }\end{array}$ & $\begin{array}{l}\text { Preterm home birth } \\
\text { at } 31 \text { weeks (a male } \\
1660 \mathrm{~g} \text { ) dmitted to } \\
\text { the neonatal ICU, } \\
\text { discharged } 6 \text { weeks } \\
\text { later } \\
4 \text { months of age } \\
\text { subvalvular and } \\
\text { valvular pulmonary } \\
\text { stenosis with a } \\
\text { pressure gradient of } \\
64 \text { mmHg } 3 \text { years of } \\
\text { age normal } \\
\text { development no } \\
\text { evidence of } \\
\text { arrhythmia or signs } \\
\text { of cardiac } \\
\text { decompensation. }\end{array}$ \\
\hline
\end{tabular}




\begin{tabular}{|c|c|c|c|c|}
\hline Authors: & $\begin{array}{l}\text { Year of } \\
\text { publication: }\end{array}$ & $\begin{array}{l}\text { Prenatal } \\
\text { diagnosis at [wks]: }\end{array}$ & $\begin{array}{l}\text { Additional } \\
\text { cardiac and/or } \\
\text { extracardiac } \\
\text { anomalies: }\end{array}$ & Follow-up: \\
\hline $\begin{array}{l}\text { McEwing RL, } \\
\text { Chaoui R. [5] }\end{array}$ & 2003 & 23 weeks & $\begin{array}{l}\text { No additional heart } \\
\text { defects or } \\
\text { arrhythmia }\end{array}$ & $\begin{array}{l}\text { Male, birth at } 38 \text { th } \\
\text { weeks } 3060 \mathrm{~g}, \\
\text { Bicuspid aortic } \\
\text { valve with normal } \\
\text { velocities across the } \\
\text { valve. } \\
\text { The child was } \\
\text { discharged at } 3 \\
\text { days, } 1 \text { year old no } \\
\text { arrhythmia or } \\
\text { additional cardiac } \\
\text { findings. }\end{array}$ \\
\hline Our case & 2020 & $33 \mathrm{wks}$ & $\begin{array}{l}\text { Criss-cross } \\
\text { Corr-TGA } \\
\text { Ao arch hypoplasia }\end{array}$ & $\begin{array}{l}\text { Male, } 40^{\text {th }} \text { weeks, } \\
\text { vaginal delivery, } \\
3000 \mathrm{~g} \text {, Apgar } 10 \\
\text { Day } 8^{\text {th }}: \\
\text { pulmonary artery } \\
\text { banding and } \\
\text { reconstruction of } \\
\text { the Ao arch } 6 \\
\text { months: } \\
\text { asymptomatic }\end{array}$ \\
\hline
\end{tabular}

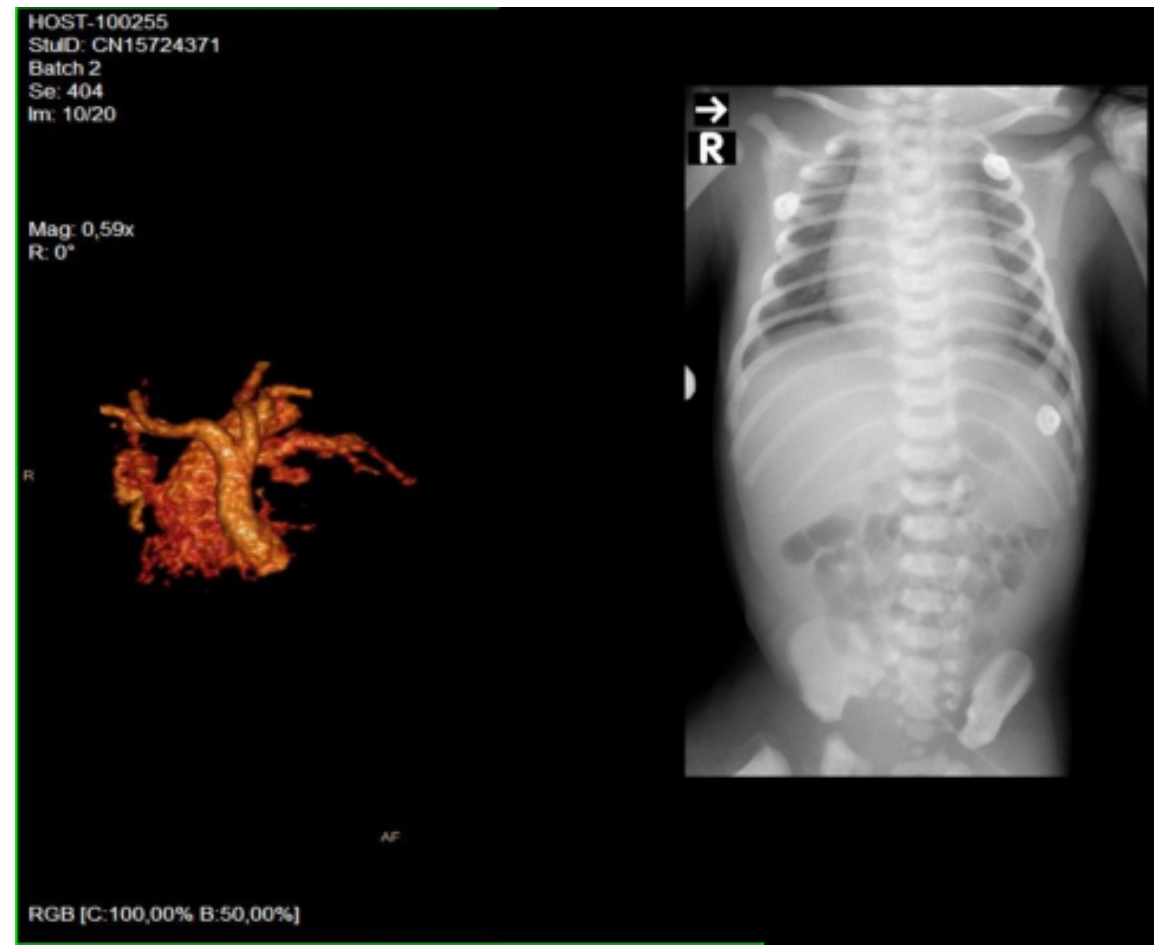




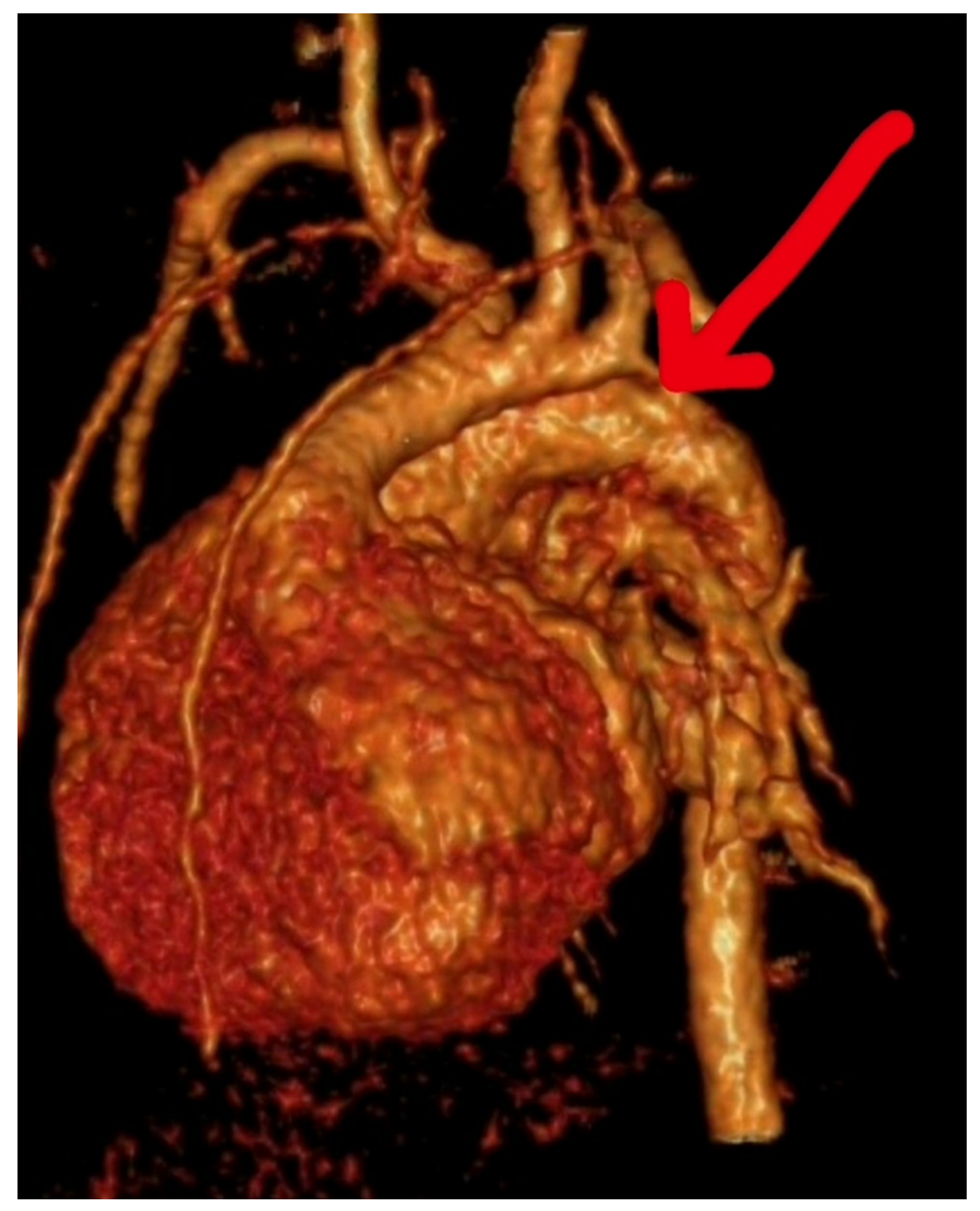

